\title{
LEF1 Gene
}

National Cancer Institute

\section{Source}

National Cancer Institute. LEF1 Gene. NCI Thesaurus. Code C80032.

This gene plays a role in both signal transduction and transcription. 